\title{
Different Cultures, Different Students, Same Test: Comparing Math Skills of Hungarian and American College Students
}

\author{
Barbara A. Price ${ }^{1}$, Cindy H. Randall ${ }^{1}$, Joshua Frederick ${ }^{1}$, József Gáll $^{2} \&$ Thomas W. Jones $^{3}$ \\ ${ }^{1}$ Department of Management, Georgia Southern University, Statesboro, GA, USA \\ ${ }^{2}$ Faculty of Economics and Business Administration, University of Debrecen, Debrecen, Hungary \\ ${ }^{3}$ Information Systems Department, University of Arkansas, Fayetteville, AR, USA \\ Correspondence: Thomas W. Jones, Information Systems Department, Sam M. Walton College of Business, \\ University of Arkansas, Fayetteville, AR 72701, USA. E-mail: twjones@uark.edu
}

Received: July 5, 2012

doi:10.5539/jel.v1n2p128

\author{
Accepted: July 27, 2012 \\ Online Published: October 15, 2012 \\ URL: http://dx.doi.org/10.5539/jel.v1n2p128
}

\begin{abstract}
In recent decades, Hungary and the United States have embraced new philosophies in their approach to teaching mathematics. Hungary's changes were driven by social and economic shifts, the U.S. by the creation of national standards. In both countries, university faculty members complain about students' poor math skills. Professors from three universities tested students in different business classes; all classes have a significant math component and require critical thinking. Analyses revealed that Hungarian students outperformed those in the U.S., that there was no difference in performance by gender, and that students who were further along in their university classes did not perform better than those who were beginning degree programs.
\end{abstract}

Keywords: math skills, business students, international

\section{Introduction}

Beginning in late 1989 and early 1990, Hungary's education system began a slow evolution from a soviet model to one that more resembled Western Europe, a journey influenced by changes in the social and economic environment (Pusztai and Szabó, 2008). While many educators favored a Western focus, there was resistance. Teachers were reluctant to alter subject areas in which national exams were administered (Kaufman and Paulston, 1991). Consequently, early changes included dropping mandated instruction in the Russian language and moving to a decentralized education plan in which decision making was returned to the local level. Communities had a voice in the education of their children, electing school boards, and hiring principals. Private schools opened (Gutsche, 1993). The value of a teacher depended on his/her subject area. Those who could teach German or English were paid a great deal more than those teaching natural and social sciences (Kaufman and Paulston, 1991).

Work on reforming the Hungarian educational system has been continuous, driven by a growing need for higher education (Pusztai and Szabó, 2008). In fact, so many changes occurred during the 1990s that this time period is referred to as "the long decade of Hungarian higher education" (Fàbri, 2002). Schools were given more freedom and financial support; teachers were raised to a more revered status (Gutsche, 1993).

Today the approach to teaching mathematics in Hungary has caught the attention of educators. It has been "suggested that the salvation of English mathematics teaching may lie in our adopting the practices used so effectively by Hungarian colleagues" (Andrews, 1997). Hungarian teaching is interactive; it engages the whole class and focuses on justification and proof (Andrews, 1997). Lessons carry a narrow focus but are multifaceted and delivered with energy and confidence (Harries, 1997). Math is considered to be worthwhile and is valued. A sense of competition, in part, pushes students to excel but also a desire to please parents and gain respect of their teacher (Andrews, 1997).

Since the advent of the 1950s, preliminary mathematics instruction in the United States has been in a constant state of reform. For the U.S., the biggest hurdle was obtaining a consortium across state lines; up until the late 1980s there was little to no national standard (Klein, 2003). In 1989, the National Council of Teachers of Mathematics (NCTM) proposed "An Agenda for Action," a document that lead to the "math wars" of the mid-1990s. The discussion is ongoing, notable in the subsequent pedagogy problems at the turn of the new century (Zaslovsky, 
2008), and the more recent reform in 2006 with NCTM's "Curriculum Focal Points for Prekindergarten through Grade 8 Mathematics" (Schielack et al., 2006).

The NCTM standards put into place during the late 1980s and early 1990s were seen by many as vague and easily misinterpreted (Klein, 2003). The NCTM standards divide learning into intervals of K-4, 5-8, and 9-12, with three different curricula to approach the end goals for each partition. The three subsets of the NCTM standards at the elementary level, funded by the National Science Foundation (NSF), were: Everyday Mathematics, Math Trailblazers, and Investigations in Number, Data, and Space. Everyday Mathematics integrated teacher and student projects for hands on experiences focused on problem solving (Baki and Gokcek, 2005). Math Trailblazers focused on real world and applied mathematics to underline mathematical use in everyday life, while Investigations in Number, Data, and Space focus on group learning through teacher led dialogue and extensive homework and note booking (Klein, 2003).

Following the implementation of the NCTM/NSF guidelines, American mathematics education seemed to be awash in conflict between the mixture of pedagogy style and mathematics. Although there was adherence to the NCTM standards at the state level (Raimi, 2000), there still remained arguments over what worked best in practice, in continuing education, and in the methods of the elementary NCTM programs (Carnine, 2000). The main argument against these NCTM platforms was the perceived failure to help students develop basic algebra and arithmetic skills, in part due to the encouragement of calculator use and the lack and/or inefficiency of elementary student projects (Klein, 2007). Graham, Li, and Buck (2000) found that in most institutions content courses are typically taught in the mathematics departments and methods are taught by the faculty of education. This may foster a perspective that methods are unrelated to content or that content is more important than methods. Ball and Bass (2000) note that there even seems to be a disconnect between teaching mathematics as a true knowledge base and forcing the discipline upon students as a stringent and pragmatic approach. These two rifts in the teaching of elementary mathematics remain the bane of mathematics education, necessitating a broad base of requirements for those teaching mathematics to young developing minds.

The requirements of mathematics educators are great; there are governmental, institutional, and familial forces pulling the teachers in different directions. Zaslovsky (2008) notes that because of the push of mathematics instructors to have the knowledge of a mathematician coupled with the structure and approach of a mentor, "the demands on teacher educators, in terms of knowledge and qualities, are enormous and multifaceted." Supporting this claim, Shulman and Grossman (1988) theorize that there are seven purviews of knowledge required by not only mathematics instructors, but all educators: subject matter, pedagogical content, other contents, curriculum, of learners, of educational aims, and general pedagogical knowledge. These requirements only add to the problems facing educators as they battle state guidelines, professional criticism, and parental backlash.

Taking into account the discord among professionals, parents, and educators, the NCTM once again attempted to strengthen preliminary mathematics instruction. In 2006, the "Curriculum Focal Points for Prekindergarten through Grade 8 Mathematics" was implemented. This program had focal points for each individual grade and hoped to lessen the inconsistency within the previous K-8 NCTM platforms (Schielack et al., 2006). However for the future of American mathematics, the boundary among educators, mathematicians, and professionals needs to be addressed. Many in the field of mathematics education indicate that "national leadership is needed to assist in future articulation of learning expectations in mathematics, particularly from national professional organizations of mathematics teachers (K-12 and university) and mathematicians" (Reys et al. 2005).

For the sake of this research, our primary interest is student performance in the international arena in higher education. The National Center for Education Statistics reported international rankings of general mathematics knowledge for students in grades 4, 8, and 12 (National Center for Education Statistics, 1999). Compared to twenty-five nations, U.S. fourth graders scored above the international average of 529 and were ranked eighth; Hungary's students were similar with an average score of 548 versus the U.S. score of 545. By grade eight, U.S. students scored an average of 500, which was below the international average of 513 and placed the U.S. at 28 out of 41 countries. Hungary's students had a mean score of 537 and were ranked $14^{\text {th }}$. By grade 12 with 21 countries participating, U.S. students were ranked $19^{\text {th }}$, followed only by Cyprus and South Africa. Hungary remained $14^{\text {th }}$ in rankings, still above the international average. In recent international rankings, students from the U.S. placed $25^{\text {th }}$ in math (McCarron, 2012).

Finger pointing to assign blame for the poor performance of U.S. students has been widespread. Historically it is states and not the federal government that control curriculum, resulting in wide-ranging expectations (Vernille, n.d.). Math curricula in the U.S. covers more topics but in less detail than curricula in Asian countries (Prystay, 2004). Tests in the U.S. are more likely to be multiple-choice versus open response, involving lower levels of 
problem solving (Vernille, n.d.). Parents in America do not view math as an essential skill (Rimer, 2008) and are less likely to hire tutors when children need help (Jackson, 2012). Regardless of the cause, the result is that 20 percent of U.S. college freshmen majoring in science or engineering need remedial math classes (Prystay, 2004).

\section{Background}

In an attempt to ascertain students' basic math skills, faculty members at two universities in the southern United States, both classified by Carnegie as a Doctoral Research University with roughly the same size student body (over 19,000) and AACSB accredited business programs, administered a problem set (see Appendix 1) to 595 students enrolled in production, business statistics, and quantitative analysis. The difficulties students experienced with basic math skills were found to be consistent from classroom to classroom, campus to campus, in classes of different levels (sophomore versus junior versus senior), and with different prerequisites (Jones, Price, \& Randall, 2011).

During the spring semester of 2011, one of these authors served as a Fulbright Lecturer at a Hungarian university similar in many respects to the universities in the original study. A key difference between the higher education systems in Hungary and the United States is that in Hungary the lecture portion of the class is delivered to a large group of students. This group is then broken into clusters of 25 to 30 students for the seminar portion of the class The faculty of the Hungarian university agreed to translate the problem set to Hungarian (see Appendix 2) and administer the basic math skills test to 230 students in two required courses in the management curriculum: microeconomics and statistics II.

The following sections compare the courses from the American and Hungarian universities including the basic content, placement of the course in the curriculum, class size, presentation method, prerequisite requirements, and student characteristics. Then, the results of the basic skills test are reported and analyzed. Finally, the observations and insights of the Hungarian and American Fulbrighter faculty members are reported and interpreted.

\section{Methodology}

In spring 2011, students in Hungary enrolled in microeconomics and statistics II were administered a basic math skills test. These two courses, as well as the courses assessed at the American universities, differ in content and placement in the curriculum (see Table 1). However, all of classes have a significant math component and force students to engage in critical thinking. The classes vary in size and in delivery. Production is generally delivered to classes of 50 students and is primarily taught through lectures. Business statistics and quantitative analysis classes are held in computer labs, limiting class size to 45 students. While there is a lecture component to these classes, the lab environment affords a hands-on element, allowing the students to actively work during class. Microeconomics lecture is offered as a mass class, drawing 178 students (for the class included in this study). The statistics II class was larger, with 337 students enrolled. Both Hungarian classes have a two hour lecture (with all students together in a large lecture room) and a two hour seminar component (organized from the large lecture portion and broken into smaller classes composed roughly of 25 to 30 students).

Table 1. Course placement and content

\begin{tabular}{|c|c|c|}
\hline Course & $\begin{array}{l}\text { Placement in } \\
\text { Curriculum }\end{array}$ & Course Content \\
\hline Production & sophomore year & $\begin{array}{l}\text { This required core course is designed to provide students with a } \\
\text { broad understanding of the production and delivery of } \\
\text { goods/services. The course focuses on concepts and } \\
\text { methodologies for managing the flow of material and } \\
\text { information throughout the production and delivery of } \\
\text { goods/services: information needs, information systems, } \\
\text { forecasting, regression, time series, managing inventory, logistics } \\
\text { network design, facility location, transportation modes, and cost } \\
\text { allocation and activity-based costing. }\end{array}$ \\
\hline Business Statistics & junior year & $\begin{array}{l}\text { This introductory course covers the concepts and techniques } \\
\text { concerning exploratory data analysis, frequency distributions, } \\
\text { central tendency and variation, probability, sampling, inference, } \\
\text { regression, and correlation. }\end{array}$ \\
\hline
\end{tabular}




\begin{tabular}{ccl}
\hline $\begin{array}{c}\text { Quantitative } \\
\text { Analysis }\end{array}$ & junior/senior year & $\begin{array}{l}\text { This class is a required junior core course that focuses on } \\
\text { scientific decision-making methods for modern day managers, } \\
\text { including such topics as linear programming, regression, } \\
\text { forecasting, project management, and decision analysis. }\end{array}$ \\
\hline Microeconomics & $\begin{array}{l}\text { semester } 2 \\
\text { (of } 6 \text { or } 7 \text { ) }\end{array}$ & $\begin{array}{l}\text { The course is aimed at making students familiar with the basic } \\
\text { concepts of microeconomic analysis. Particularly, the course } \\
\text { focuses on the analysis of how economic actors, consumers and } \\
\text { firms, choose between different alternatives. By the end of the } \\
\text { course, students should be able to use the basic tools and models } \\
\text { of microeconomics, and apply them in solving problems. }\end{array}$ \\
& semester 4 \\
(of 6 or 7 ) & $\begin{array}{l}\text { This course covers the basic concept of hypothesis tests, } \\
\text { parametric hypothesis tests (for means, variances and population } \\
\text { proportions) as well as some further tests for goodness of fit and } \\
\text { independence. The second half deals with regression analysis, } \\
\text { both simple and multiple, and some basic time series methods } \\
\text { (smoothing, trends, seasonality, forecasting). }\end{array}$ \\
\hline
\end{tabular}

These five classes differ in course prerequisites (see Table 2). The two classes taught at the Hungarian university have fewer prerequisites, allowing them to be placed earlier in the program of study.

Table 2. Course prerequisites

\begin{tabular}{|c|c|c|c|c|c|}
\hline Prerequisites & Production & $\begin{array}{l}\text { Business } \\
\text { Statistics }\end{array}$ & $\begin{array}{l}\text { Quantitative } \\
\text { Analysis }\end{array}$ & $\begin{array}{l}\text { Microeconomics } \\
\text { (Hungary) }\end{array}$ & $\begin{array}{l}\text { Statistics II } \\
\text { (Hungary) }\end{array}$ \\
\hline Finite Math & $\mathrm{X}$ & & & & \\
\hline Business Calculus & & $\mathrm{X}$ & & & \\
\hline Business Statistics & & & $\mathrm{X}$ & & \\
\hline $\begin{array}{l}\text { Fundamentals of } \\
\text { Business }\end{array}$ & $\mathrm{X}$ & $\mathrm{X}$ & & & \\
\hline $\begin{array}{l}\text { Advanced Business } \\
\text { Applications }\end{array}$ & & $\mathrm{X}$ & & & \\
\hline $\begin{array}{l}\text { Legal Environment } \\
\text { of Business }\end{array}$ & $\mathrm{X}$ & $\mathrm{X}$ & & & \\
\hline $\begin{array}{l}\text { Data Analysis and } \\
\text { Interpretation }\end{array}$ & $X$ & & & & \\
\hline $\begin{array}{l}\text { Financial } \\
\text { Accounting }\end{array}$ & & $\mathrm{X}$ & & & \\
\hline Microeconomics & $\mathrm{X}$ & & & & \\
\hline Macroeconomics & & $\mathrm{X}$ & & & \\
\hline Statistics I & & & & & $\mathrm{X}$ \\
\hline $\begin{array}{l}\text { Introduction to } \\
\text { Economics }\end{array}$ & & & & $\mathrm{X}$ & \\
\hline
\end{tabular}

It should be noted that Statistics II has as its prerequisite Statistics I. However, Business Mathematics, which is largely a calculus class, serves as the prerequisite for Statistics I. Therefore, the Hungarian students are completing a calculus course as part of their degree program.

The composition of the classes in Hungary by gender differed from those in the U.S. A greater percent of the students in Hungary were female (over 50 percent). The classes at the American universities had a higher percent 
of males (see Table 3). The Hungarian students outscored the U.S. students on the math skills assessment, scoring 84 percent or more correct versus roughly 72 percent correct.

Table 3. Student characteristics

\begin{tabular}{llll}
\hline Course & Females & Males & Overall \% Correct \\
\hline Production & $29.9 \%$ & $70.1 \%$ & $72.6 \%$ \\
Business Statistics & $39.1 \%$ & $60.9 \%$ & $71.4 \%$ \\
Quantitative Analysis & $35.5 \%$ & $64.5 \%$ & $72.0 \%$ \\
Microeconomics & $65.7 \%$ & $34.3 \%$ & $90.4 \%$ \\
Statistics II & $53.1 \%$ & $46.9 \%$ & $84.5 \%$ \\
\hline
\end{tabular}

\section{Data Analysis}

The 15 problems on the math skills assessment were marked as correct or incorrect, with no partial credit given. First, the results were compared for the five groups (production, statistics, and quantitative analysis students in the U.S. study and microeconomics and statistics students in Hungarian study). The overall mean percentage of correct answers was compared along discipline lines and the inequality of the overall mean percentage correct for the five groups was tested for significance using ANOVA. For this we tested first the homogeneity of variances of the different groups by Levene's test, and the Welch test was also run as an alternative of the one-way ANOVA for the case of unequal variances. Based on the results of the above tests, in-depth analysis of the identified differences was conducted.

Next, the data were divided by student nationality. The test results of the U.S. students were compared problem by problem to the test results of the Hungarian students. The overall mean percentage of correct answers was compared for the two groups and the inequality of the overall mean percentage correct for the two groups was tested for significance using ANOVA or Welch test, based on the results of Levene's test.

Finally, the data were divided by student gender. The performance on the problem set for the female students was compared to the performance of the male students. The overall mean percentage of correct answers was compared for the two groups and the inequality of the overall mean percentage correct for the two groups was tested for significance using ANOVA or Welch test, based on the results of Levene's test.

\section{Results}

The following hypotheses were tested:

$\mathrm{H}_{\mathrm{o}}$ : There is no difference in the mean percent correct response per question by discipline.

$\mathrm{H}_{\mathrm{o}}$ : There is no difference in the mean percent correct response between nationalities.

$\mathrm{H}_{0}$ : There is no difference in the mean percent correct response between genders.

Using the mean percent correct response of the students enrolled in the five different subjects, box plots were created to illustrate the difference in performance of the groups (see Figure 1). The mean percent correct response among the production students was $72.6 \%$ (with a standard deviation of .207), among the statistics students it was $71.4 \%$ (with a standard deviation of .193), among the quantitative analysis students it was $72.0 \%$ (with a standard deviation of .191), among the statistics II students it was $84.5 \%$ (with a standard deviation of 0.148), and among the microeconomics students it was $90.4 \%$ (with a standard deviation of 0.107 ). Thus, the Hungarian classes outperformed the American students on average and the variation in mean scores for the Hungarians was much less. However, there were a few extreme low score outliers in the Hungarian scores. 


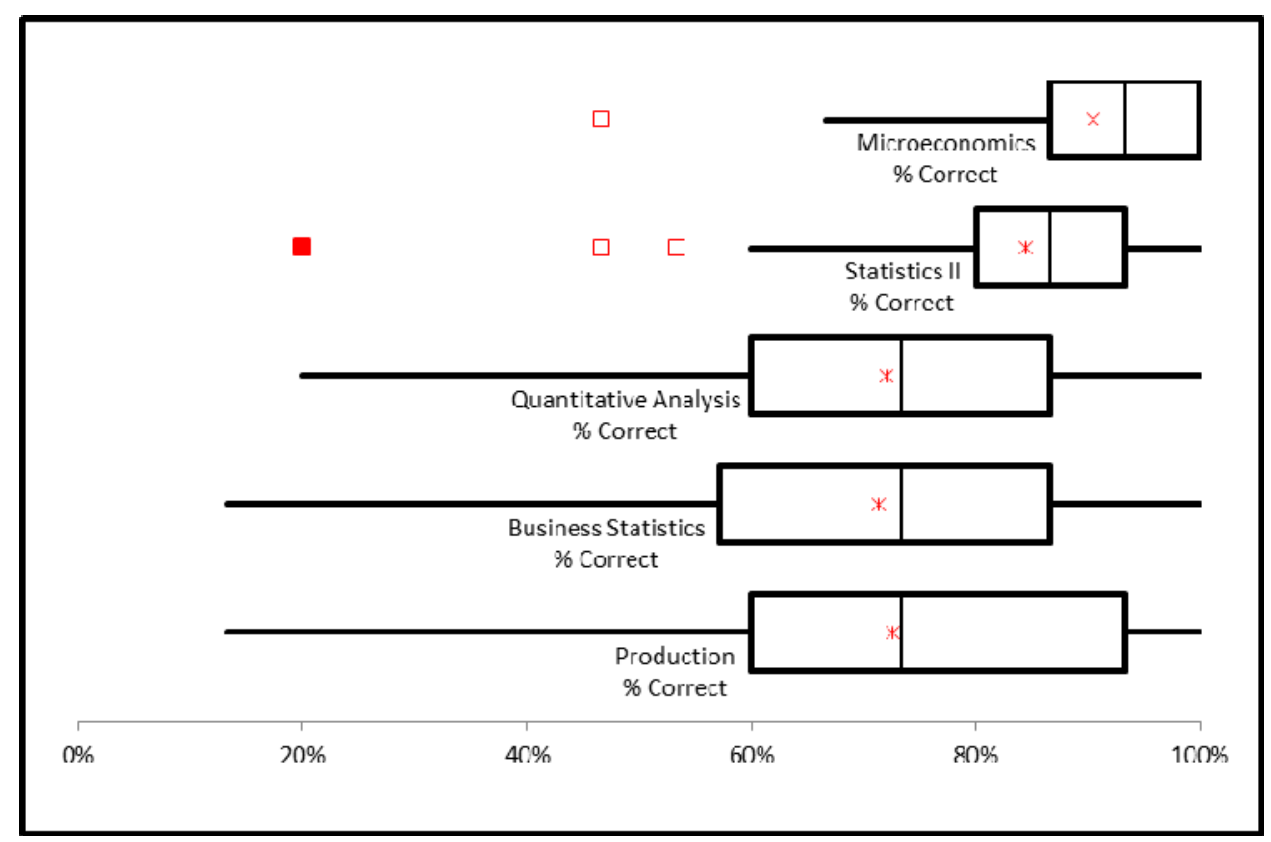

Figure 1. Box plot comparing overall mean percent correct by discipline

It was interesting to note that while the Hungarian students had a higher mean percent correct response than their American counterparts on all but one problem, the patterns of the five disciplines on the line chart is roughly the same (see Figure 2). The Hungarian students outperformed the U.S. students on every question except a problem in which students were asked to express a percent as a decimal. For this question, there was confusion in the translation of the problem. The Hungarian faculty members believed that this had an impact in the mean response rate of their students. As shown in Figure 2, while the Hungarians performed better, they still had difficulty with the same concepts that stymied the American students. The problem set incorporated operations of arithmetic as well as the order of operations for the first five questions (1(a) through 1(e)), decimal and percent conversions (questions 2 through 5), algebra (questions 6(a) through 6(d)), and numerical substitution into and evaluation of formulas (questions 7(a) and 7(b)). 


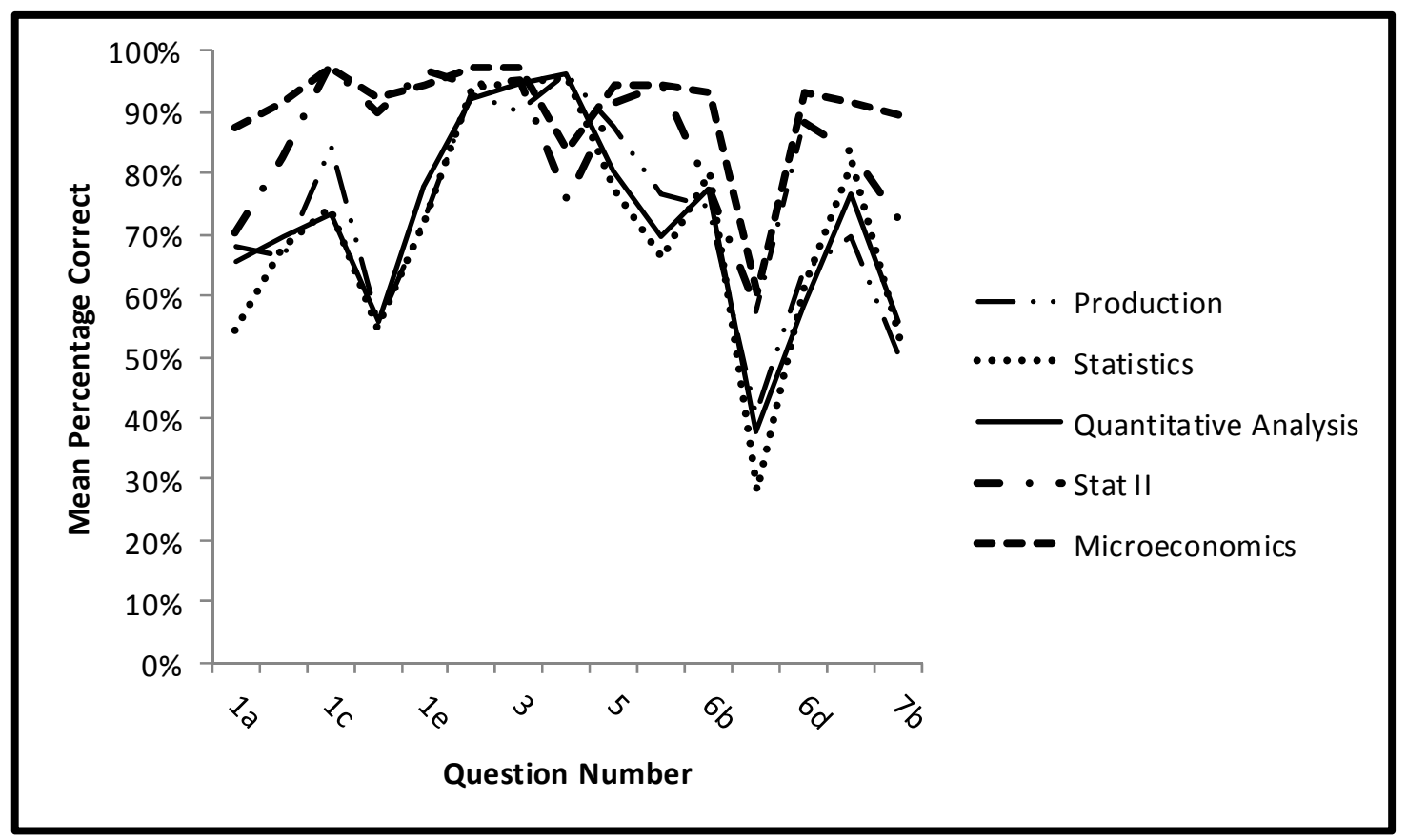

Figure 2. Mean percent correct response by question by discipline

ANOVA and Welch tests were employed to statistically determine whether or not there was a significant difference in the mean percent correct responses of the five disciplines (see Table 4). The Levene's test shows that the equality of variances was rejected ( $p$-value $<0.0001)$, hence one should use the Welch test rather than the one-way ANOVA. The Welch test generated a p-value of $<0.0001$. The $p$-value failed to support the conviction of the researchers that there was no significant difference between the mean performances of students by discipline. Therefore, $\mathrm{H}_{\mathrm{o}}$ was rejected. Research Hypothesis 1 was not supported.

This finding was not consistent with prior results. Jones, Price, and Randall (2011) compared the mean responses from the production, business statistics, and quantitative analysis students. The subsequent ANOVA test generated an F-ratio of .2099 and a p-value of .8107. The p-value supported their hypothesis that there was no significant difference between the mean performances of students from these three disciplines. When data from the two classes in Hungary was included, the results failed to support the hypothesis of no difference in mean performance by the five disciplines. The significant difference found when comparing the mean response of the five disciplines can be attributed to the inclusion of data from the Hungarian students.

Table 4. ANOVA results comparing mean percent correct response by discipline

\begin{tabular}{|c|c|c|c|c|c|}
\hline & \multirow{3}{*}{$\begin{array}{l}\text { Production } \\
\% \text { Correct }\end{array}$} & \multirow{3}{*}{$\begin{array}{l}\text { Business } \\
\text { Statistics } \\
\% \text { Correct }\end{array}$} & \multicolumn{2}{|l|}{ Quantitative } & \multirow{3}{*}{$\begin{array}{l}\text { Microeconomics } \\
\% \text { Correct }\end{array}$} \\
\hline & & & Analysis & Statistics II & \\
\hline & & & $\%$ Correct & $\%$ Correct & \\
\hline Sample size & 184 & 230 & 181 & 127 & 104 \\
\hline Sample mean & 0.7261 & 0.7135 & 0.7204 & 0.8446 & 0.9045 \\
\hline Sample std. dev. & 0.2074 & 0.1933 & 0.1910 & 0.1479 & 0.1070 \\
\hline Sample variance & 0.0430 & 0.0374 & 0.0365 & 0.0219 & 0.0115 \\
\hline Pooling weight & 0.2229 & 0.2789 & 0.2192 & 0.1535 & 0.1255 \\
\hline One-way ANOVA & Sum of & Degrees of & Mean & & \\
\hline Table & Squares & Freedom & Squares & & \\
\hline Between variation & 4.0684 & 4 & 1.0171 & 31.0010 & $<0.0001$ \\
\hline Within variation & 26.9359 & 821 & 0.0328 & & \\
\hline Total variation & 31.0043 & 825 & & & \\
\hline
\end{tabular}




\begin{tabular}{|c|c|c|c|c|}
\hline & Test Statistic & $\begin{array}{l}\text { Degrees of } \\
\text { Freedom } 1\end{array}$ & $\begin{array}{l}\text { Degrees of } \\
\text { Freedom } 2\end{array}$ & p-value \\
\hline Levene test & 16.9264 & 4 & 821 & $<0.0001$ \\
\hline Welch test & 52.5755 & 4 & 387.7880 & $<0.0001$ \\
\hline
\end{tabular}

Looking deeper into the data, a comparison was made to determine which differences contributed to the change in findings with respect to disciplines. Clearly, the multiple comparisons in Table 5 indicated that on average the students in the Hungarian courses performed better than the students in the American courses and that the first year Hungarian students performed significantly better than the more advanced Hungarian students. Both of these results were interesting and significant.

Table 5. Pairwise multiple comparisons

\begin{tabular}{|c|c|c|c|}
\hline \multirow[b]{2}{*}{ Group Means Compared ${ }^{\text {a }}$} & \multirow{2}{*}{$\begin{array}{l}\text { Difference of } \\
\text { Means }\end{array}$} & \multicolumn{2}{|c|}{ 95\% Confidence Intervals } \\
\hline & & Lower & Upper \\
\hline Percent correct A-B & 0.0125 & -0.0226 & 0.0477 \\
\hline Percent correct $\mathrm{A}-\mathrm{C}$ & 0.0056 & -0.0316 & 0.0429 \\
\hline Percent correct A- D ${ }^{* *}$ & -0.1185 & -0.1595 & -0.0775 \\
\hline Percent correct $\mathrm{A}-\mathrm{E}^{* *}$ & -0.1784 & -0.2220 & -0.1348 \\
\hline Percent correct B - C & -0.0069 & -0.0422 & 0.0284 \\
\hline Percent correct B $-\mathrm{D}^{* *}$ & -0.1311 & -0.1704 & -0.0918 \\
\hline Percent correct B $-\mathrm{E}^{* *}$ & -0.1909 & -0.2330 & -0.1489 \\
\hline Percent correct $C-D^{* *}$ & -0.1242 & -0.1653 & -0.0830 \\
\hline Percent correct $C-E^{* *}$ & -0.1840 & -0.2278 & -0.1403 \\
\hline Percent correct $\mathrm{D}-\mathrm{E}^{* *}$ & -0.0599 & -0.1069 & -0.0128 \\
\hline \multicolumn{4}{|c|}{$\begin{array}{l}{ }^{a} \text { Groups } \mathrm{A}, \mathrm{B} \text {, and } \mathrm{C} \text { denote the three American courses (production, busines } \\
\text { statistics, and quantitative analysis, respectively). Groups D and E denote the twc } \\
\text { Hungarian courses (statistics II and microeconomics). } \\
{ }^{* *} \text { The difference of means is statistically significant. }\end{array}$} \\
\hline
\end{tabular}

Comparing the mean percent correct by nationality, box plots were created to illustrate the difference in performance of the two groups (see Figure 3). The mean percent correct response among the Hungarian students was $87.2 \%$ (with a standard deviation of .134) while the mean percent correct response among the students in the U.S. was $71.9 \%$ (with a standard deviation of .197). 


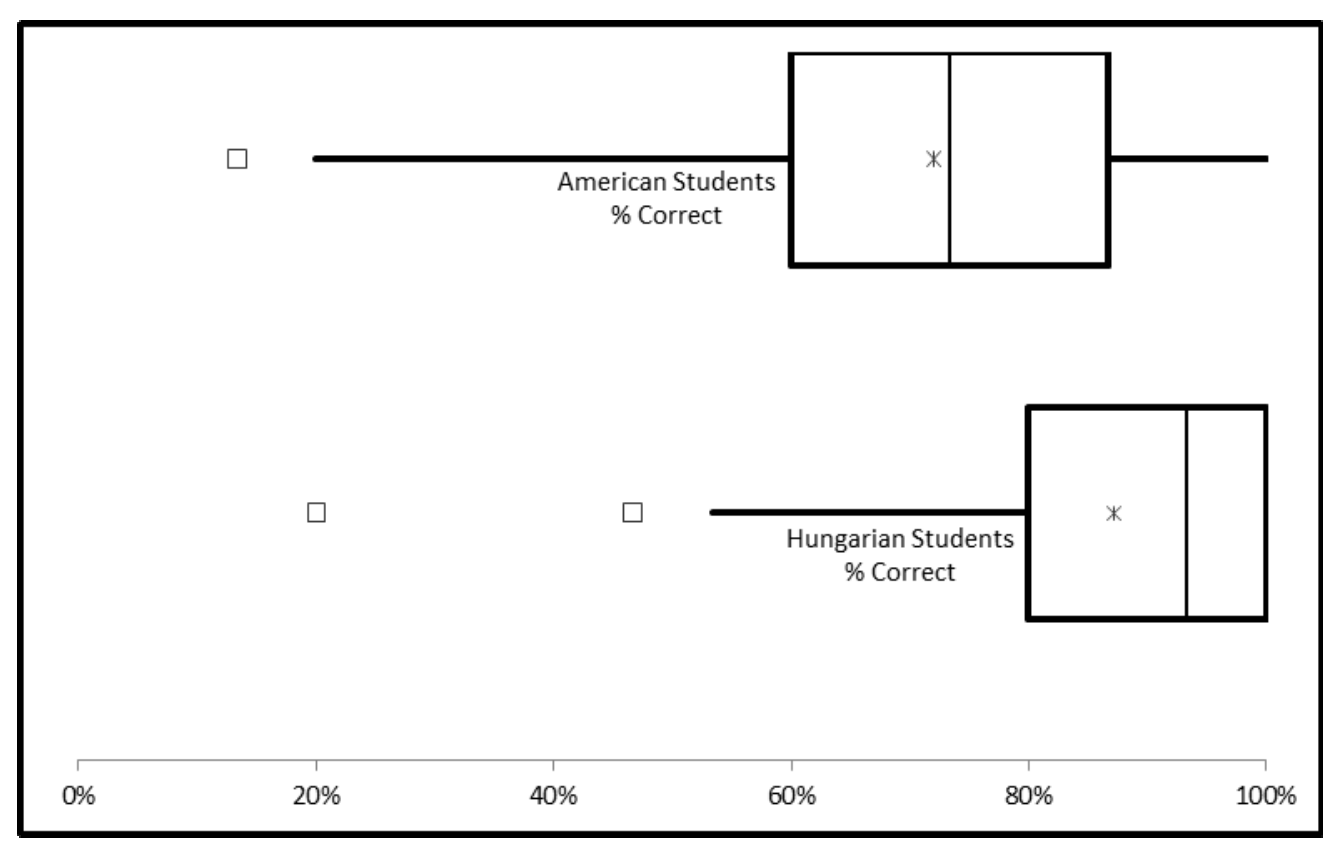

Figure 3. Box plot comparing overall mean percent correct by nationality

A line chart plot is provided, plotting the mean percent correct response by question by nationality (see Figure 4). Again, it illustrates that Hungarian students outperformed U.S. students.

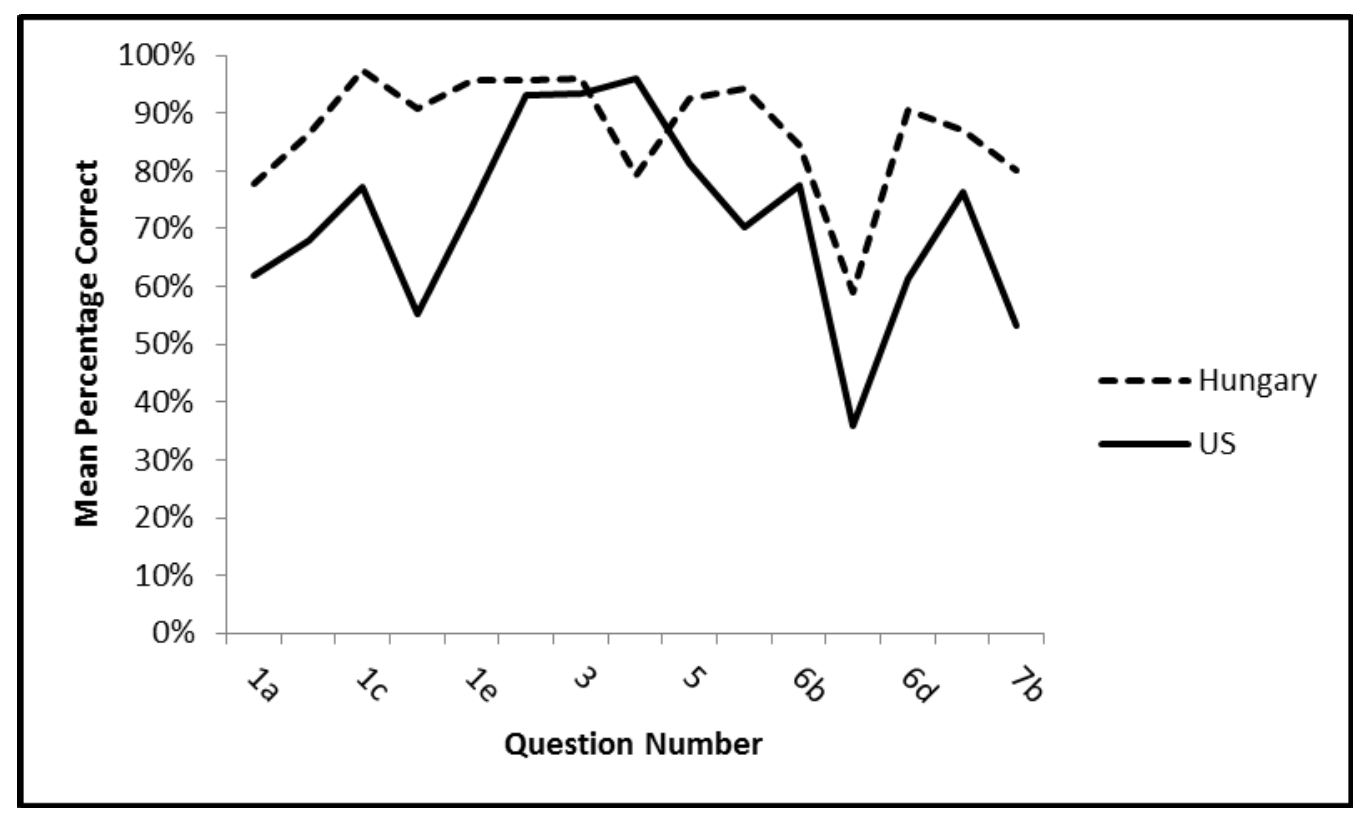

Figure 4. Mean percent correct response by question by nationality

ANOVA and Welch tests were employed to statistically determine whether or not there was a significant difference in the mean percent correct responses between nationalities (see Table 6). Based on the Levene's test, we rejected the equality of variances of the different groups (countries). Hence we turned to the Welch test which produced a $p$-value of $<0.0001$. The $p$-value failed to support the conviction of the researchers that there was no significant difference between the mean performances of Hungarian versus American students. Therefore, $\mathrm{H}_{\mathrm{o}}$ 
was rejected. Research Hypothesis 2 was not supported.

Table 6. ANOVA results comparing mean percent correct response by nationality

\begin{tabular}{|c|c|c|c|c|c|}
\hline & Hungarian & American & & & \\
\hline & Students & Students & & & \\
\hline & $\%$ Correct & $\%$ Correct & & & \\
\hline Sample size & 231 & 595 & & \multirow[b]{7}{*}{ F-ratio } & \multirow[b]{7}{*}{ p-value } \\
\hline Sample mean & 0.8716 & 0.7195 & & & \\
\hline Sample std. dev. & 0.1342 & 0.1968 & & & \\
\hline Sample variance & 0.0180 & 0.0387 & & & \\
\hline Pooling weight & 0.2791 & 0.7209 & & & \\
\hline \multirow{2}{*}{$\begin{array}{l}\text { One-way ANOVA } \\
\text { Table }\end{array}$} & Sum of & Degrees of & Mean & & \\
\hline & Squares & Freedom & Squares & & \\
\hline Between variation & 3.8472 & 1 & 3.8472 & 116.7300 & $<0.0001$ \\
\hline Within variation & 27.1571 & 824 & 0.0330 & & \\
\hline \multirow[t]{3}{*}{ Total variation } & 31.0043 & 825 & & & \\
\hline & & Degrees of & Degrees of & & \\
\hline & Test Statistic & Freedom 1 & Freedom 2 & & p-value \\
\hline Levene test & 58.6173 & 1 & 824 & & $<0.0001$ \\
\hline Welch test & 161.6060 & 1 & 610.0070 & & $<0.0001$ \\
\hline
\end{tabular}

Comparing the mean percent correct responses by gender, box plots were created to illustrate the difference in performance of the two groups (see Figure 5). The mean percent correct response among female students was $76.6 \%$ (with a standard deviation of .188) while the mean percent correct response among male students was $75.9 \%$ (with a standard deviation of .198). 


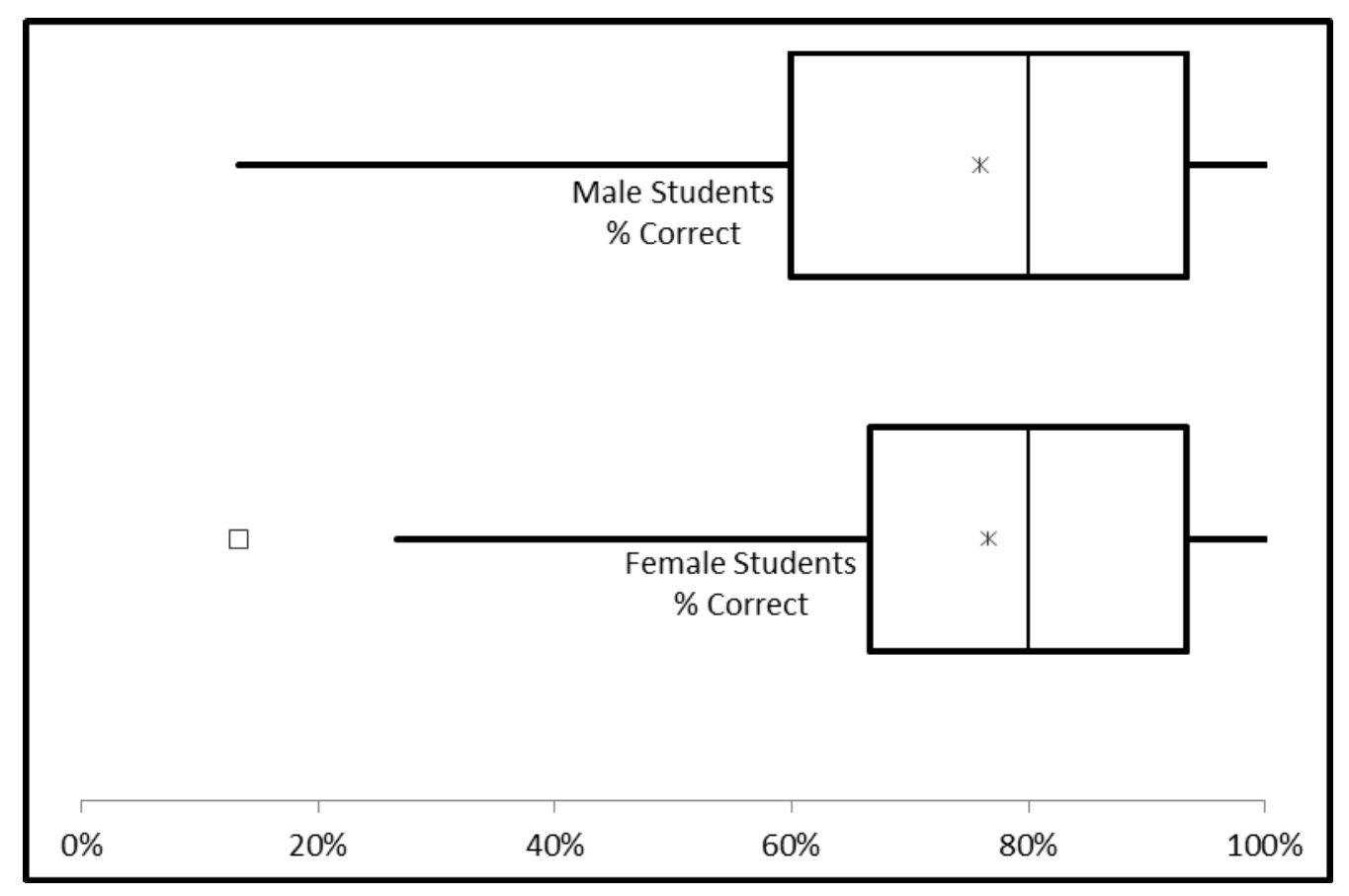

Figure 5. Box plot comparing overall mean percent correct by gender

ANOVA was employed to statistically determine whether or not there was a significant difference in the mean percent correct responses between genders (see Table 7). The Levene's test gave a p-value $=0.2130$, thus the equality of variances can be accepted. Therefore, we turned next to the one-way ANOVA which generated an F-ratio of .238 and a p-value of .614. The p-value supported the conviction of the researchers that there was no significant difference between the mean performances of females versus male students. Therefore, Ho was not rejected. Research Hypothesis 3 was supported.

Table 7. ANOVA results comparing mean percent correct response by gender

\begin{tabular}{|c|c|c|c|c|c|}
\hline & $\begin{array}{l}\text { Female } \\
\text { Students } \\
\text { \% Correct }\end{array}$ & $\begin{array}{l}\text { Male } \\
\text { Students } \\
\text { \% Correct }\end{array}$ & & & \\
\hline Sample size & 353 & 472 & & & \\
\hline Sample mean & 0.7663 & 0.7595 & & & \\
\hline Sample std. dev. & 0.1879 & 0.1981 & & & \\
\hline Sample variance & 0.0353 & 0.0392 & & & \\
\hline Pooling weight & 0.4277 & 0.5723 & & & \\
\hline $\begin{array}{l}\text { One-way ANOVA } \\
\text { Table }\end{array}$ & $\begin{array}{l}\text { Sum of } \\
\text { Squares }\end{array}$ & $\begin{array}{l}\text { Degrees of } \\
\text { Freedom }\end{array}$ & $\begin{array}{l}\text { Mean } \\
\text { Squares }\end{array}$ & F-ratio & $\mathrm{p}$-value \\
\hline Between variation & 0.0093 & 1 & 0.0093 & 0.2483 & 0.6184 \\
\hline Within variation & 30.9076 & 823 & 0.0376 & & \\
\hline \multirow{2}{*}{ Total variation } & 30.9169 & 824 & & & \\
\hline & Test Statistic & $\begin{array}{l}\text { Degrees of } \\
\text { Freedom } 1\end{array}$ & $\begin{array}{l}\text { Degrees of } \\
\text { Freedom } 2\end{array}$ & & $\mathrm{p}$-value \\
\hline Levene test & 1.5533 & 1 & 823 & & 0.2130 \\
\hline Welch test & 0.2522 & 1 & 778.4823 & & 0.6157 \\
\hline
\end{tabular}




\section{Observations and Conclusions}

The findings of the data analyses are consistent with the informal observations of the Fulbright Professor.

- During her six months lecturing in Hungary, the professor found the students' technical math skills to be significantly better than the students she has been teaching in the United States for almost 40 years.

- However, it appeared that the strength of technical skills was not retained as the students moved through the program.

- In addition, although the Hungarian students possessed stronger technical skills, they did not appear to have stronger abilities in applying and interpreting the results of analyses.

- Gender did not appear to be a factor in mathematical abilities. That is, the differences were found by nationality of the students, not the gender.

What conclusion can be reached? Clearly any conclusions are primarily observational and anecdotal. The research cannot support a cause and effect relationship between pre-college mathematical training and the technical mathematical skills demonstrated by the American and Hungarian university students. However, based on the significant findings, the data indicate that the Hungarian university students have better mastered the basic arithmetic concepts and skills tested in the project. Considering the concerns many faculty have regarding math skills of students in quantitative courses, the results of this study provide impetus to delve more deeply into the causes and perhaps develop recommendations to address the concerns.

Many students exhibit a lack of basic math skills. Students, who lack mastery of these concepts, possess deficiencies which put them at a disadvantage in learning material that is dependent upon these concepts. Faculty must recognize these deficiencies exist and be prepared to assist students to overcome these weaknesses. As the earlier article by Jones et al. (2011) noted, a course was developed at one of the studied universities that could address the observed mathematical weaknesses; however, the proposal stalled at the college level. Based on the results presented here, the authors plan on reinitiating the approval process.

\section{Acknowledgements}

This research has been partially supported by the Hungarian Scientific Research Fund under Grant No. OTKA K 79128/2009. The authors thank Carol Waller, Office of Publications and Faculty Research Services, College of Business Administration, Georgia Southern University, for her efforts in preparing this paper for publication.

\section{References}

Andrews, P. (1997). A Hungarian perspective on mathematics education. The Association of Teachers of Mathematics (ATM), 161, 14-17.

Baki, A., \& Gökçek, T. (2005). Comparison of the development of elementary mathematics curriculum studies in Turkey and the U.S.A. Educational Sciences: Theory \& Practice, 5(2), 579-588.

Ball, D. L., \& Bass, H. (2000). Interweaving content and pedagogy in teaching and learning to teach: Knowing and using mathematics. In J. Boaler (Ed.), Multiple perspectives on the teaching and learning of mathematics (pp. 83-104). Westport, CT: Ablex.

Carnine, D. (2000). Why education experts resist effective practices. Thomas B. Fordham Foundation.

Fàbri, György. (2002). Az akadémia és a mindentudàs egyeteme. Vilàgossàg, 10-12(8-14).

Graham, K. J., Li, Y., \& Buck, J. C. (2000). Characteristics of mathematics teacher preparation programs in the United States: An exploratory study. The Mathematics Educator, 5(1/2), 5-31.

Gutsche, M. (1993). The Hungarian education system in the throes of change. European Education, 25(2), 5-11. http://dx.doi.org/10.2753/EUE1056-493425025

Harries, T. (1997). Reflections on a mathematics lesson in Kaposvar. The Association of Teachers of Mathematics (ATM), 161, 11-13.

Jones, T. W., Price, B. A., \& Randall, C. H. (2011). A comparative study of student math skills: Perceptions, validation, and recommendations. Decision Sciences Journal of Innovative Education, 9(3), 379-394. http://dx.doi.org/10.1111/j.1540-4609.2011.00314.x

Jackson, B. (2012). Why other countries do better in math. The Daily Riff - Be Smarter About Education. Retrieved from http://www.thedailyriff.com/articles/why-other-countries-do-better-in-math-520.php (July $19,2012)$ 
Kaufman, C. C., \& Paulston, R. G. (1991). Hungarian education in transition. Presented at the Annual Conference of the American Educational Research Association (AERA), Chicago, IL (April).

Klein, D. (2003). A brief history of American K-12 mathematics education in the $20^{\text {th }}$ century. In J. Royer (Ed.), Mathematical cognition: A volume in current perspectives on cognition, learning, and instruction (pp. 175-225). Edited by James Royer, Charlotte: Information Age Publishing.

Klein, D. (2007). A quarter century of U.S. "Math Wars" and political partisanship. Journal of the British Society for the History of Mathematics, 22(1), 22-33.

National Center for Education Statistics. (1999). Overview and key findings across grade levels. Highlights from TIMSS: the Third International Mathematics and Science Study. Office of Education Research and Improvement. U.S. Department of Education, NCES 1999-081. July 23, 2012 Retrieved from http://nces.ed.gov/pubs99/1999081.pdf (July 23, 2012)

McCarron, S. (2012). Let's solve our math and science challenges. Perspectives. Retrieved from http://www.exxonmobilperspectives.com/2012/04/08/lets-solve-our-math-and-science-challenges (July 19, 2012)

Prystay, C. (2004). As math skills slip, U.S. schools seek answers from Asia. The Wall Street Journal Online (December 13). Retrieved from http://www.wsj.com

Pusztai, G., \& Szabó, P. C. (2008). The Bologna Process as a Trojan horse: Restructuring higher education in Hungary. European Education, 40(2, Summer), 85-103.

Raimi, R. A. (2000). Judging state standards for K-12 mathematics education. In S. Stotsky (Ed.), What's at stake in the K-12 standards wars: A primer for educational policy makers (pp. 33-58). New York: Peter Lang.

Reys, B. J., Dingman, S., Sutter, A., \& Teuscher, D. (2005). Development of state-level mathematics curriculum documents: Report of a survey. Columbia, Mo.: University of Missouri, Center For the Study of Mathematics Curriculum.

Rimer, S. (2008). Math skills suffer in U.S., study finds. The Richard Dawkins Foundation for Reason and Science. Retrieved from http://richarddawkins.net/articles/3231-math-skills-suffer-in-u-s-study-finds

Schielack, J. F., Beckman, S., Charles, R. I., Clements, D. H., Duckett, P. B., Fennell, F., Lewandowski, S. L., Treviño, E., \& Zbiek, Rose M. (2006). Curriculum focal points for prekindergarten through grade 8 mathematics: A quest for coherence. National Council of Teachers of Mathematics.

Shulman, L. S., \& Grossman, P. (1988). Knowledge growth in teaching: A final report to the Spencer Foundation. Technical Report of the Knowledge Growth in a Profession Research Project. Stanford, CA: School of Education, Stanford University.

Vernille, K. (2012). Why are U.S. Mathematics students falling behind their international peers? Retrieved from http://www-users.math.umd.edu/ dac/650/vernillepaper.html (July 19, 2012)

Zaslovsky, O. (2008). Meeting the challenges of mathematics teacher education through design and use of tasks that facilitate teacher learning. In B. Jaworski \& T. Wood (Eds.), The international handbook of mathematics teacher education, vol. 4: The mathematics teacher educator as a developing professional (pp. 93-114). Rotterdam: Sense Publishers.

\section{Appendix 1}

1. Perform the indicated operations for each of the following expressions without using a calculator.

(a) $26+34 / 2=$

(b) $29-37-18=$

(c) $3 / 2+1=$

(d) $6-2 \times 14=$

(e) $3+4(20-17)=$

2. Express .01 as a percentage.

3. Express 3/4 as a percentage. 
4. Express 3 percent as a decimal.

5. 2 is what percentage of 8 ?

6. Solve each of the following expressions for $\mathrm{x}$.

(a)

$$
\frac{39}{3+x}=3
$$

(b)

$$
11 \mathrm{x}+3000=7 \mathrm{x}+8000
$$

(c) $3 \sqrt{\mathrm{x}}=45$

(d)

$$
Z=\frac{X-M}{S}
$$

7. Evaluate each of the following formulas without using a calculator assuming that $A=108, C=-4, N=6$, and $\mathrm{S}=312$.

(a)

$$
M=\frac{A}{N}+C
$$

(b)

$$
X=\sqrt{\frac{S}{N}-C^{2}}
$$

\section{Appendix 2}

\section{Matematikai készségek}

Név

1. Végezze el az alábbi műveleteket számológép használata nélkül!
(a) $26+34 / 2=$
(b) $29-37-18=$
(c) $3 / 2+1=$
(d) $6-2 \times 14=$
(e) $3+4(20-17)=$

2. Fejezze ki 0,01-et százalékos formában!

3. Fejezze ki 3/4-et százalékos formában!

4. Fejezze ki a $3 \%$-ot a tizedestört alakban!

5. A 2 hány százaléka a 8-nak?

6. Mennyi az x értéke az alábbi kifejezésekben?
(a) $\quad \frac{39}{3+\mathrm{x}}=3$
(b) $\quad 11 \mathrm{x}+3000=7 \mathrm{x}+8000$
(c) $3 \sqrt{\mathrm{x}}=45$
(d) $\quad Z=\frac{X-M}{S}$

7 Oldja meg az alábbi egyenleteket, ha feltételezzük, hogy: $\mathrm{A}=108, \mathrm{C}=-4, \mathrm{~N}=6, \mathrm{~S}=312$. 
(a)

$$
M=\frac{A}{N}+C
$$

(b)

$$
X=\sqrt{\frac{S}{N}-C^{2}}
$$

8. Neme:

Férfi

Nő

9. szak

10. Évfolyam
(a) év
(b) év
(c) év
(d) év
Posztgraduális

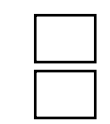

Posztgraduát

Egyetértek azzal, hogy válaszaimat tudományos kutatás céljára felhasználják. Tudomásul veszem, hogy sem a jövőbeli kutatási tevékenység, sem az összegyüjtött adatok nem fognak azonosítható utalásokat tartalmazni a válaszaimra. A kérdőív anonim, a válaszadó személye az adatbázisban nem azonosítható.

Translation:

I agree that my answers can be used for scientific research. I understand that any future research or data collected will not be identifiable references to be included in the answers. The questionnaire is anonymous; the respondent's identity in the database cannot be identified. 